Revista Monografias Ambientais

Santa Maria, Edição Especial Curso de Especialização em Educação

Ambiental. 2015. 2015, p. 45-65

Revista do Centro de Ciências Naturais e Exatas - UFSM

\title{
Análise do Gerenciamento dos Residuos Sólidos em Panambi-RS: 1955 á 2012
}

\author{
Analysis of Solid Waste Management in Panambi-RS: \\ 1955 to 2012
}

\author{
Cléa Hempe ${ }^{1}$, Carlos Alberto da Fonseca Pires ${ }^{2}$ \\ ${ }^{1}$ Mestra, Tutora Presencial Polo UAB Panambi (RS), Curso de Especialização em Educação Ambiental-UFSM (RS), \\ Professora concursada da rede Municipal de Panambi (RS), Brasil. \\ 2 Doutor, Orientador e Coautor Associado da UFSM, RS, Brasil.
}

\section{Resumo}

O objetivo geral desta pesquisa consistiu em realizar um resgate histórico e geográfico do gerenciamento dos resíduos sólidos. O estudo foi realizado utilizando-se da pesquisa qualitativa, deste modo foi possível refletir, analisar e se posicionar sobre as ações dos gestores públicos. Ao longo das gestões públicas municipais de 1955 a 2012, estiveram à frente da administração sete gestores, sendo que três administraram apenas uma gestão, dois administraram duas gestões e dois administraram três gestões. O município de Panambi, ao longo dos 57 anos, teve três lugares onde foi realizado o depósito de resíduos sólidos. A partir do referencial teórico e da busca através da pesquisa de campo, foi possível realizar as análises e perceber que cada gestor teve o seu conceito de gerenciamento dos resíduos sólidos e sua forma de administração. Houve consórcio, terceirização e, por último, os serviços estão sendo realizados pelos funcionários da prefeitura. No primeiro lugar de estudo, constatou-se que a Prefeitura Municipal apenas oferecia os serviços de recolhimento e era levado para um terreno distante a um $\mathrm{km}$ do centro urbano, literalmente era um grande lixão. A preocupação estava em afastar do centro da cidade os resíduos. No segundo lugar houve uma evolução no gerenciamento dos serviços, passou de lixão para aterro controlado, e foi construída uma usina de triagem. No terceiro lugar, houve evolução de aterro controlado para aterro sanitário, e foi construída uma usina de triagem, dentro de padrões modernos. Panambi tem se destacado na região da AMUPLAM, a qual faz parte na maneira de realizar o gerenciamento dos seus resíduos sólidos, embora precise avançar muito para ser considerada modelo.

Palavras Chaves: Resíduos Sólidos; Legislação; Gerenciamento; Gestor Público Municipal.

\begin{abstract}
The general objective of this research consisted in conducting a historical and geographical review on the solid waste management from 1955 to 2012. The study was conducted using the qualitative research, where it was possible to reflect, analyze and position on the actions of the public officials. Over the city public administrations from 1955 to 2012 , there were seven administrators whereas three of them managed only one term, two managed for two terms and two managed for three terms. Panambi city had three places where they held the solid waste disposal. From the theoretical framework and search through the field research it was possible to carry out the analysis where we realized that each administrator had their own concept of solid waste management and administration. There were a consortium, outsourcing and ultimately the services have been carried out by city employees. At the first place of study, it was found that the city government only offered the services of collection and the waste was taken to an area far from the urban center, it was literally a big rubbish dump. The concern was keeping the waste away from the city center. The second place showed an evolution in the management of services, it had changed from a rubbish dump to a recycling plant with a controlled landfill and at the third place they started with a recycling plant and sorting with a controlled landfill and after they invested in the construction of a sanitary landfill. Panambi has excelled in the region of AMUPLAM, which is part of the way to perform the management of solid waste, although much progress is needed for it to be considered a model.
\end{abstract}

Keywords: Solid Waste, Legislation, Management, City Public Administrator. 


\section{Introdução}

Este artigo traz resultados da pesquisa realizada no Curso de Mestrado em Geografia e Geociências realizada nos anos de 2011 a 2012, na área de Concentração Análise Ambiental e Dinâmica Espacial e na linha de pesquisa Geoinformação e Sensoriamento Remoto em Geografia, na Universidade Federal de Santa Maria-RS.

O problema da pesquisa consistiu em verificar como ocorreu o gerenciamento dos resíduos sólidos no município de Panambi/RS e as formas de destinação final adotadas pela Administração Pública Municipal de 1955 a 2012.

A pesquisa teve como objetivo geral realizar um resgate histórico e geográfico sobre a gestão dos resíduos sólidos no município, nas Administrações Públicas Municipais de 1955 a 2012.

Os objetivos específicos consistiram em: Localizar os lugares que foram depósito de resíduos sólidos no município e descrever como ocorreu o gerenciamento no período compreendido entre 1955 a 2012; Conhecer, descrever e analisar a unidade operacional e os serviços na Central de Triagem e Compostagem que está operando no município de Panambi/RS; Conhecer o perfil dos funcionários públicos que desempenham suas funções na Usina de Triagem, a fim de colher informações e sugerir ações a Administração Pública Municipal; Identificar e nomear as ações dos diferentes gestores municipais com relação aos resíduos sólidos, construindo uma cronologia para ser visualizada, apresentada à comunidade panambiense e subsidiar novas ações dos gestores públicos.

A dissertação, a qual resultou este artigo, foi apresentada em quatro capítulos, sendo eles: Resíduos Sólidos: Considerações Gerais, Caracterização do Município de Panambi-RS, Abordagem Teórica-Metodológica e Gestão dos Resíduos Sólidos no município de Panambi-RS. Este artigo apresenta de forma sucinta alguns dos resultados obtidos.

\section{Abordagem Teórica - Metodológica}

Para elaboração da pesquisa sobre os lugares de depósitos de resíduos sólidos utilizados nas Administrações Públicas Municipais optou-se pela Pesquisa Qualitativa, que segundo Triviños (1987, p.124) é conhecida também como: "estudo de campo, estudo qualitativo, interacionismo simbólico, perspectiva interna, etnometodologia, ecológica, descritiva, observação participante, entrevista qualitativa, abordagem de estudo de caso entre outras".

O estudo de caso distinguiu três tipos. A pesquisa enquadrou-se no Estudo de Caso Histórico Organizacional, porque o interesse recaiu sobre a vida de uma Instituição Pública (TRIVINOS, 1987).

A pesquisa foi baseada na técnica da triangulação. Os eixos principais dessa técnica se desenvolvem em torno de três: processos e produtos centrados na instituição, elementos produzidos pela instituição e processos e produtos originados pela estrutura- sócio - econômica e cultural do macro organismo.

No eixo processos e produtos centrados na instituição realizou-se entrevista com gestores que atuaram nas administrações municipais. As questões foram abertas e visou tirar dúvidas, a partir das leituras realizadas nos diversos materiais que existiam no Museu e Arquivo Histórico Professor Hermann Wegermann e materiais disponibilizados pelo responsável no Setor do Meio Ambiente da Prefeitura Municipal, bem como diversos materiais existentes na Biblioteca Adil Alves Malheiros, entre outros. Realizaram-se também entrevistas com os responsáveis pelos trabalhos burocráticos na Prefeitura Municipal e todos os funcionários que trabalhavam na Central de Tratamento de Resíduos Sólidos - CTCAS. Realizam-se observações em dias diferentes nos três lugares de depósitos de resíduos sólidos. $\mathrm{Na}$ Central de Triagem as 
observações ficaram em torno de como é realizado o trabalho pelas diferentes equipes no dia-adia.

No segundo eixo elementos produzido pela instituição, em relação aos instrumentos legais realizaram-se levantamentos e análises de leis, decretos, pareceres, resoluções e regimentos (escalas nacional, estadual e local); Já referente aos documentos oficiais examinaram-se atas de reuniões do Conselho Municipal do Meio Ambiente e da Arpa Fiúza. Realizou-se levantamento referente à quantidade de resíduos que entravam na Central de Triagem tanto dos orgânicos quanto dos reciclados e de terceiros, de agosto a dezembro de 2011, a assiduidade dos funcionários que desempenham suas funções na Central de Triagem, etc. Pesquisou-se sobre: os destinos dos resíduos sólidos no Brasil, destinação final por região do Brasil, por municípios do Brasil servido por coleta seletiva, entre outros. Também foram feitos levantamentos de dados gerais para caracterizar o urbano panambiense.

No eixo três modo de produção, foi necessário fazer algumas adaptações, os dados levantados ficaram em torno de saber como se dão as relações de trabalho, ou seja, como são admitidos os funcionários que estão desempenhando as funções no Central de Triagem - Rincão Frente.

Após a segunda visita aos lugares de estudos - trabalho de campo, sentiu-se a necessidade de elaboração de um plano de observação com o intuito de facilitar as análises dos dados. Para isto, inspirado em Mol (2007) elaborou-se alguns parâmetros para ser utilizados como variáveis para análise. Segundo (MOL, 2007, p.32) "As listagens apresentam como vantagem a simplicidade da construção, a facilidade da sistematização das informações, a capacidade de sumarizar os resultados, a rapidez da aplicação e o baixo custo".

Os mapas apresentados na pesquisa foram reelaborados a partir dos Mapas do Plano Diretor elaborado pela Prefeitura no ano de 2008. A elaboração destes tiveram como base cartográfica as cartas topográficas da Primeira Diretoria de Serviços Geográficos do Exército Brasileiro em escala 1: 50.000, elaboradas nos anos 1960 a 1970. Tendo essa base georreferenciada e disponibilizada pela Prefeitura Municipal, utilizaram-se os mapas para localizar as áreas pesquisadas. Para melhor localização das áreas fez-se o levantamento de coordenada em cada local de estudos, após foram representados nos mapas. Com referência a planta urbana a Prefeitura Municipal havia feito a aquisição de uma imagem de satélite IKONOS com 1 metro de resolução espacial, de abril de 2006, imagem georreferenciada e ortoretíficada. Sobre esta imagem foram realizados todos os mapeamentos da área urbana e realizada conferência a campo em locais que não apresentassem clareza nas informações. Para localizar os lugares de estudo do presente trabalho na referida planta utilizou-se a mesma sistemática. Empregaram-se as coordenadas coletadas a campo com GPS de navegação, e em seguida inseridas na planta urbana.

A mesma sistemática foi empreendida na seleção de alguns pontos levantados em cada lugar de estudo, para localizar estes pontos utilizou-se o software Google Earth. Cada lugar foi delimitado e inserido as coordenadas geográficas levantadas de cada ponto escolhido para o presente estudo, bem como análise dos mesmos. Nas imagens aéreas foram cruzadas com imagens realizadas a campo. Algumas coordenadas geográficas encontradas descritas no Projeto de Recuperação de Área Degradada estavam em coordenadas UTM (metros). Estas foram transformadas em coordenadas decimais, utilizando-se do programa disponível no endereço eletrônico http://codigopostal.ciberforma.pt/ferramentas/converter-coordenadas/. Após a localização dos pontos fez-se uma foto da imagem com a localização dos pontos, utilizando-se da tecla Prt Sc SysRq do teclado e colou-se no programa paint, fez-se os ajustes necessários e inseriuse no trabalho. 


\section{Referencial Teórico}

Os resíduos sólidos passam a ser problema quando "em quantidade e qualidade tal que impeça o desenvolvimento harmônico dos seres vivos em dado ecossistema e já vem preocupando os homens há milhares de anos, em função das epidemias de doenças surgidas pela contaminação de águas" (CASTRO, 2003, p.94).

Após a Revolução Industrial agravou-se a situação ambiental, uma vez que houve aperfeiçoamento das tecnologias, que gerou melhores condições de vida na sociedade, contribuindo para o aumento da população e gerando a necessidade de produção em massa, a fim de atender a demanda crescente de consumo. Diante da explosão populacional e de consumo, estima-se que, em média, cada pessoa produz em torno de um quilo de resíduo por dia. No Brasil, calcula-se que são produzidas aproximadamente 240 mil toneladas de resíduos sólidos no mesmo período e, por dia, o total pode chegar a 86,4 milhões de toneladas por ano (DIAS, 2006). A adequação dos destinos dos resíduos nos vários municípios brasileiros é ainda um grande desafio neste século XXI.

O desafio da limpeza urbana vai além de remover o lixo de logradouros e edificações, isto é, principalmente é necessário dar destino final correto aos resíduos coletados. Em grande número das municipalidades brasileiras, o sistema de limpeza urbana está em segundo plano e a prioridade é a coleta e a limpeza urbana. É comum observar os municípios de pequeno porte a presença de "lixões". Nesses locais, o lixo é coletado e jogado diretamente sobre o solo sem qualquer controle e cuidados ambientais, vindo com o decorrer do tempo a poluir o solo, o ar e as águas subterrâneas e superficiais (MONTEIRO, 2001).

Em pesquisa realizada pela Associação Brasileira de Empresas de Limpreza Pública e Resíduos Especiais - ABRELPE (2009), constatou-se que no Brasil existem 5.565 municípios, sendo que destes 38,4\% (2.138 municípios) utilizam aterro sanitário, 31,2\% (1.739 municípios), possuem aterro controlado e 30,3\% (1688 municípios) depositam os residuos sólidos em lixões.

Nos municípios onde não existe a coleta seletiva, os resíduos são muitas vezes jogados no meio ambiente causando grandes impactos a paisagem. A paisagem é objeto de interesse e de estudo para o jurista especializado em direito urbanístico, para o geógrafo, para o urbanista, para o paisagista, entre outras profissões.

A paisagem sob o ângulo da Geografia constitui tema central para a compreensão dos diferentes aspectos da organização do espaço. Para Libório (2011, p.1) “(...) as inter-relações estabelecidas pelos diversos enfoques científicos é o cenário de nossas experiências cotidianas, devem estar centradas em pontos comuns para que possam, de fato, ser propiciadoras de medidas efetivas para a sua proteção."

A paisagem precisa ser vista além do que é visível, observável, buscar as explicações do que está por detrás da paisagem, a busca de significado do que aparece (CALLAI, 2000).

O estudo do conceito de lugar só ganhou importância para a Geografia a partir da década de 1980. Desde a implantação da Geografia como disciplina acadêmica - o conceito de lugar foi eventualmente estudado pelos geógrafos, mas sempre em um plano secundário. Estudar as paisagens de um determinado lugar é, portanto, compreender a realidade. "As paisagens trazem a marca das culturas e, ao mesmo tempo, as influenciam" (CLAVAL, 1999, p.318). Para Santos (1998, p.65) "A paisagem é um conjunto heterogêneo de formas naturais e artificiais, é formada por frações de ambas".

Callai (2000, p.111) "sugere analisar as paisagens fazendo a leitura do que está expresso e que a nossa visão apreende, percebendo a história, o movimento, a mobilidade territorial." A autora recomenda buscar e identificar os fixos e reconhecer os fluxos em suas origens e nas formas de concretização material. O espaço é sempre formado de fixos e fluxos. Cada tipo de fixo (área de estudo) surgiu com características, que são técnicas organizacionais do município na 
época. Os fluxos são o movimento, a circulação e assim eles nos dão também, a explicação dos fenômenos da distribuição e o consumo, podem ser estudados através desses dois elementos: fixos e fluxos.

Ao longo da história, segundo Álamo (1994), o homem tem demonstrado que possui capacidade para alterar o meio ambiente que o rodeia de forma deliberada e inconsciente. As mudanças e alterações que ocorrem na paisagem dependem em grande parte de medidas e de formas como as pessoas percebem seu entorno e os objetivos e aspirações que têm em relação ao uso, modificações e adaptações desses meios a suas necessidades.

\section{Resultados e Discussão}

A Administração Pública Municipal de 1955 até dezembro de 2012 utilizou três "Lugares para Depósito de Resíduos Sólidos".

O primeiro lugar utilizado pela Administração Pública Municipal situava-se no Bairro Zona Norte, entre as coordenadas geográficas $28^{\circ} 16^{\prime} 44.00^{\prime \prime S}$ de Latitude e $53^{\circ} 30^{\prime} 9.80^{\prime \prime} \mathrm{O}$ de Longitude.

O segundo lugar localizava-se na BR 158, Linha Serrana entre as coordenadas geográficas $28^{\circ} 19^{\prime} 8.74$ "S de Latitude e 5329'39.17" O de Longitude.

O terceiro lugar localiza-se na Linha Rincão Frente entre as coordenadas geográficas $28^{\circ} 15^{\prime} 50.73^{\prime \prime S}$ Latitude e 53³1'26.78" O de Longitude. No último lugar mencionado localiza-se também a atual Usina de Compostagem e Triagem com Aterro Sanitário que está operando no Município de Panambi/RS, distante $4 \mathrm{~km}$ do perímetro urbano. A previsão para depósito no aterro sanitário é até o ano de 2025, conforme estudos realizados pela Empresa STC Resíduos Sólidos Ltda.

A Figura 1 - Mapa de Panambi: Zona Urbana e Rural apresenta a localização dos Lugares de Depósitos de Resíduos Sólidos, utilizados pelas Administrações Públicas Municipais da emancipação do munícipio a dezembro de 2012.

O primeiro lugar destinado para depósito de resíduos sólidos (1955 a 1974) foi cedido por duas Empresas a Prefeitura Municipal de Panambi/RS. No setor do cadastro da Prefeitura Municipal de Panambi consta a localização no Setor 1, na rua da Palmeira, bairro Zona Norte.

A área do terreno disponibilizado era de 3.408 metros quadrados. Ao lado sul, oeste e norte atualmente fazia/faz divisa com terrenos de propriedades particulares. Segundo entrevistas com moradores antigos e próximos desse lugar, os resíduos eram jogados em toda a extensão, onde hoje tem mato e pertence a proprietários particulares. O local do terreno "cedido" foi demarcado no ano de 1984, quando foi medido a área, por herdeiros. 


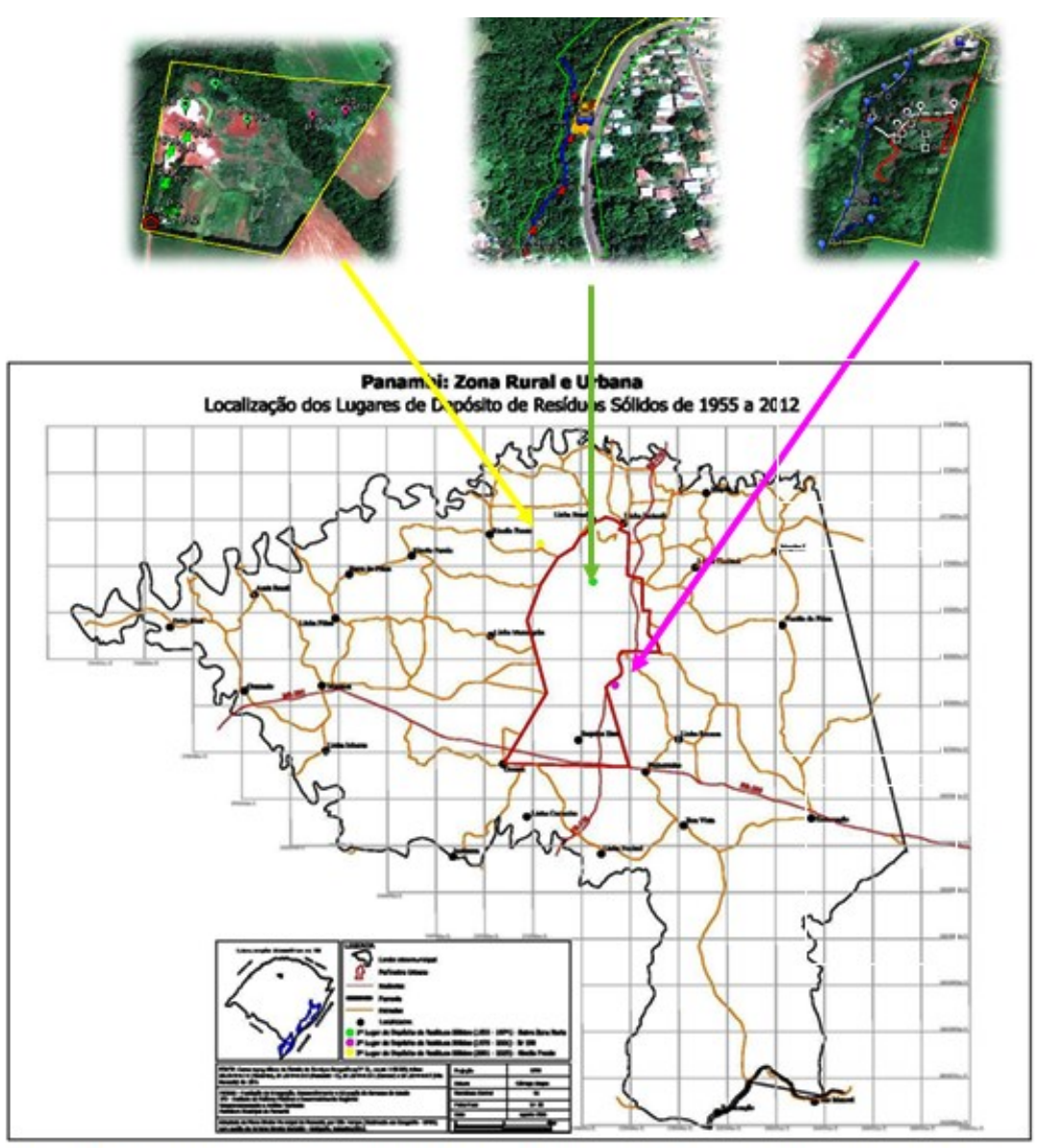

Figura 1 - Mapa de Panambi Zona Rural e Urbana:Localização dos Lugares de Depósitos de Residuos Sólidos de 1955 a 2012

Fonte: Adaptado do Plano Diretor pela Autora, 2013.

No serviço de conservação e limpeza das ruas da cidade, a Prefeitura Municipal mantinha um funcionário permanente, sendo que nos sábados o mesmo tinha a colaboração de uma turma completa e do caminhão. Periodicamente o trabalho era reforçado por turmas extranumerárias compostas por indigentes e desajustados sociais, os quais procediam à extinção das ervas daninhas, a obstrução das valetas e a limpeza do arroio que atravessava a cidade. Nos relatórios municipais anuais constam que não era possível disponibilizar verbas para contratar funcionários permanentes (RAMP,1960). A limpeza da cidade era realizada por apenas um funcionário. A partir de julho de 1962 foi contratado mais um funcionário, para ajudar nos serviços de limpeza e conservação das ruas na cidade (RELATÓRIO ANUAL DA PREFEITURA MUNICIPAL DE PANAMBI-RS-RAMP, 1962). Na vila Condor, no ano de 1962 foi contratada uma pessoa para fazer a limpeza em média três dias por semana. As pessoas responsáveis pela área de Condor não admitiam ter um funcionário fixo para esse fim (RAMP, 1962).

No período de 1959 a 1963 foram adquiridos dois carrinhos de mão e baldes coletores de lixo em abundância. Estes baldes de lixo foram colocados à disposição de todas as casas comerciais, tanto na zona urbana de Panambi como na vila de Condor. No período de (1969 -1973). Durante o primeiro semestre do ano de 1969 os resíduos passaram a ser recolhidos uma vez por semana e a orientação da Administração Pública Municipal era que as pessoas não deveriam colocar seus resíduos nas ruas fora do dia estabelecido. Segundo relato de um ex-vereador da época, algumas pessoas de posse 
pagavam gorjeta para que os garis recolhessem seus lixos nos dias não estabelecidos. Para solucionar o problema foi criada a taxa de limpeza pública. O projeto entrou na pauta da reunião do dia 02 de junho de 1969 e fixava uma alíquota de 0,33\% do salário mínimo para cada serviço que fosse realizado fora do dia estabelecido para realização dos serviços de recolhimento do lixo (O PANAMBIENSE, 1969).A população foi aumentando e o lugar onde eram depositados os resíduos na rua da Palmeira, Zona Norte não deu mais conta.

Outro problema é que a zona urbana estava crescendo para o bairro Zona Norte onde estava localizado o "Primeiro Lugar de Depósito de Resíduos Sólidos". Esse lugar ficava aproximadamente $2 \mathrm{~km}$ da Praça Central. A população passou a reclamar do mau cheiro que vinha dos resíduos, muitas pessoas pobres reviravam o lixo em busca de algo que pudessem utilizar e ou vender, animais como urubus, ratos entre outros passaram a fazer parte desse lugar.

A Administração Pública Municipal adquiriu outro lugar para depositar os resíduos sólidos, através da lei $\mathrm{n}^{\circ} 352 / 73$ de 20 de outubro de 1973. Esse se localizava próximo a BR 158, na época ainda não existia asfalto, e ficava distante do perímetro urbano. A escolha foi porque ficava perto da maior empresa que existia em Panambi. O Primeiro Lugar de Depósito de Resíduos na rua da Palmeira foi desativado em dezembro de 1974 e os resíduos passaram a ser depositado no terreno adquirido na BR 158.

A Figura 2 apresenta imagem aérea do Primeiro Lugar de Depósito de Resíduos Sólidos utilizados pelo poder público municipal. Este localizava-se no Bairro Zona Norte. A legenda apresenta pontos que foram selecionados para análise, após trabalho de campo realizado em três datas diferentes.

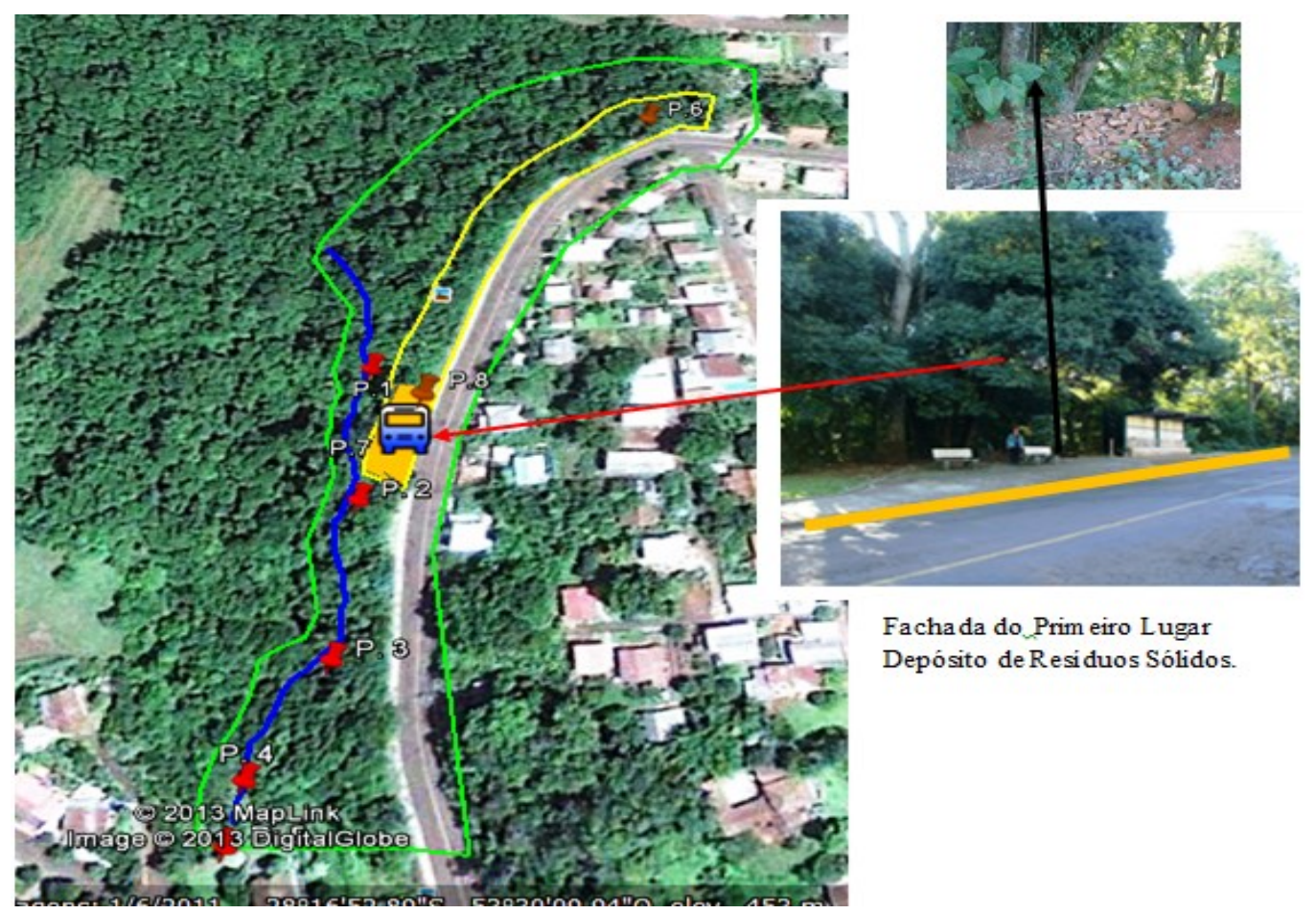

Figura 2 - Primeiro Lugar de Depósito de Resíduos Sólidos Fonte: Google Earth e Trabalho de Campo, maio 2013.

Organizado pela Autora. 


\begin{tabular}{|c|c|}
\hline & P.1 a P.4 - Trecho do rio (observações) \\
\hline & P.5 - Início da canalização do riacho \\
\hline 34 & P.6 - Problemas Ambientais \\
\hline 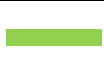 & P.7 - Delimitação do Primeiro Lugar de Depósito de Resíduos Sólidos \\
\hline 包 & P.8 - Resíduos diversos depositados em lugar inadequados \\
\hline 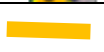 & Fachada do Primeiro Depósito de Resíduos Sólidos \\
\hline
\end{tabular}

A delimitação na cor amarela na imagem aérea corresponde ao espaço que era depositado os resíduos, além do terreno que havia sido determinado para esta finalidade.. A Figura 2 mostra trecho do riacho (P.1 a P.4), onde foram realizadas três observações no período de janeiro de 2011 a dezembro de 2012 com intervalo de três meses. Nas observações notou-se a presença de resíduos diversos na água e preso as margens. Os resíduos sólidos estavam expostos e sem cobertura de terra.

No ponto (P.5) inicia o processo de canalização do riacho. Na margem esquerda do riacho observou-se grande quantidade de resíduos de jardinagem, que foram jogados pela população que reside nas proximidades. Na margem direita, há restos de madeira, plásticos, pneus, entre outros. Nas três observações em meses diferentes, durante o ano de 2012 percebia-se que a ação antrópica era recente. As construções de moradias existentes nas proximidades do riacho respeitam a legislação das APP's.

Nos pontos (P.6 e P.8) identificou-se uma enorme quantidade de resíduos descartados pela população apesar da Prefeitura Municipal disponibilizar serviços de coleta de porta em porta. No entorno do Primeiro Lugar de Depósito dos Resíduos Sólidos, na Rua da Palmeira tinha/ainda tem problemas ambientais, mas também se constata que foram realizados investimentos na Administração Municipal 2005 a 2008, isso é, foram construídos passeios pela Administração Pública Municipal ao longo da rua, parada de ônibus e as vias públicas foram asfaltadas. Esta parada de ônibus foi construída justamente em frente de parte do Primeiro Lugar que foi Depósito de Resíduos Sólidos até o ano de 1974.

No Primeiro Lugar de Depósito de Resíduos Sólidos o passivo ambiental é visível. Segundo a Associação Brasileira de Normas Técnicas (2007), os passivos ambientais são definidos como "danos infligidos ao meio natural por uma determinada atividade ou pelo conjunto de ações humanas, que podem ou não ser avaliados economicamente".

Em entrevista realizada com famílias que residem próximo ao Primeiro Lugar de Depósito de Resíduos Sólidos relatam que não foi realizado trabalho de recuperação, após a desativação do lixão e a paisagem que existe foi recompondo-se ao longo do tempo. Esse lugar não está cercado, existem vestígios de resíduos sólidos presentes no solo, após 37 anos de desativação.

Segundo os relatos dos descendentes de moradores que ainda residem neste local após a desativação do primeiro Lugar dos Resíduos Sólidos, foram construídos inúmeras residências e os terrenos, por estarem próximas do Centro da cidade, ou seja, da Praça Engenheiro Walter Faulhaber, voltaram à valorização e a especulação imobiliária. 
O Segundo Lugar de Depósito de Resíduos Sólidos (1975 a 2001) no Município de Panambi foi adquirido de Nelita Weidle, conforme escritura pública lavrada em 06 de novembro de 1973, pelo tabelião Paulo Weber, a saber, uma fração de terras, com a área de oito (8) hectares e sete mil e quinhentos (7.500) metros quadrados, sem benfeitorias, situada na Linha Serrana, no município de Panambi, zona rural, confrontando ao norte, com terras da firma Kepler Weber S. A, ao sul e oeste, com terras de Aristeu Kersting, ao leste com terras da Prefeitura Municipal, cujo imóvel destina-se ao depósito e a conservação do lixo recolhiło na cidade.

$\mathrm{Na}$ separação dos resíduos, entretanto, o plástico era um grande problema, pois era impossível a sua decomposição e este vinha geralmente mesclado junto com os materiais orgânicos, o que gerava odor e proporcionava um habitat perfeito para os insetos. Para dar fim ao grande volume de detritos que aumentava dia-a-dia, os plásticos eram queimados com o aval do Poder Executivo. Porém, reclamações começaram a ser feitas, pois a fumaça tóxica originada da queima dos plásticos era trazida pelo vento para a área urbana e algo deveria ser feito pelo Executivo para solucionar o problema.

Em 1984 o assunto da instalação de uma Usina de Reciclagem de Lixo Urbano surgiu por parte da Administração Pública Municipal de Panambi, porém, somente no segundo semestre de 1986 formou-se uma equipe para pensar na elaboração de um Projeto. Segundo relatos de gestores do município, o Projeto da Usina de Reciclagem de Lixo foi pensada e idealizada pela Administração Pública Municipal e começou a ser colocado em prática em julho de 1986. O modelo adotado na Usina de Reciclagem de Lixo passou a operar como um protótipo idealizado e constituído por indústrias, em conjunto com técnicos e engenheiros da Prefeitura e outros municípios passaram a adotar a sistemática.

Segundo registros nos jornais locais, nos primeiros quatro meses de experiência com a usina em operação, foram tratados 15 mil toneladas diárias e com a venda dos materiais recicláveis que eram separados e comercializados pela própria prefeitura, pagava $40 \%$ a $50 \%$ da folha de pagamento dos funcionários que trabalhavam na Usina de Reciclagem de Lixo (A NOTÍCIA ILUSTRADA, 1988).

Após a instalação da Usina de Reciclagem de Lixo na BR 158, o município recebeu visita de representantes de outros municípios do RS, SC, RJ além de representação da Argentina. Os visitantes tinham o objetivo de conhecer o protótipo da usina e saber mais detalhes sobre a eficiência da mesma.

O depósito de materiais recicláveis foi construído parte de alvenaria e parte em madeira. Este possuía vários boxes para colocar os materiais que eram separados pelos funcionários.

Em relação à retirada de entulhos provenientes da limpeza de quintais, a população precisava apenas solicitar a retirada ligando para o setor encarregado na Prefeitura. A Administração Pública Municipal (1989-1992) colocou em pontos estratégicos das vias públicas, nos diferentes bairros, recipientes coletivos próprios para o armazenamento dos resíduos domésticos, era para facilitar e agilizar o recolhimento dos resíduos urbano, tanto para os garis como para a população em geral, com a finalidade de deixar a cidade mais limpa. Também havia pessoal encarregado da limpeza pública e pintura dos cordões de meio fio em ruas principais, objetivando o embelezamento da cidade e a melhoria da área urbana (A NOTÍ́CIA ILUSTRADA, 1991).

Em 1992 a Administração Pública Municipal inscreveu vários projetos para concorrer a seleção de alguns que seriam apresentados na ECO 92. O município de Panambi foi selecionado entre os oitos semifinalistas de todo o Brasil, no Programa de Reconhecimento aos gestores locais, iniciativas das Nações Unidas que premiaram os municípios que estavam com projetos ou ações em andamento o qual tinha a finalidade de proteger o Meio Ambiente. Panambi destacouse no Projeto "Usina de Reciclagem e Compostagem do Lixo". 
Em abril de 1997 houve um grande incêndio na usina de reciclagem de lixo (A NOTICIA ILUSTRADA, 1997), após este episódio, houve discussão nas emissoras de rádio e jornais locais sobre a possibilidade de implantação da coleta seletiva de resíduos sólidos. O gestor se pronunciou sobre o episódio, a Promotoria Pública enviou oficio solicitando medidas imediatas para solucionar o problema na Usina. Em fim foi dado ao gestor até o final da Administração Pública Municipal daquele período para relocar a Usina para outro espaço. Este novo espaço deveria ser longe do perímetro urbana.

A coleta seletiva de resíduos sólidos no município de Panambi (RS) teve início no mês de fevereiro de 2000, após estudos chegou-se a um cronograma que obteve êxito em diversas cidades, o qual baseava em escolher um bairro piloto, posterior implantação em toda a área urbana do município; foi elaborado e distribuído Calendário de Coleta Seletiva, o qual trazia/traz explicações e benefícios para a humanidade e meio ambiente e já com as datas de recolhimento do lixo orgânico e seco. Elaborou-se também um audiovisual, o qual-apresentava à cidade, o crescimento, as indústrias, a estrutura educacional, com texto elaborado a partir das imagens mostrando a usina e a unidade de Curitiba como exemplo. Realizaram-se palestras nas escolas contendo falas e o audiovisual sobre a educação ambiental, foram distribuídas cartilhas entre os alunos incentivando-os a serem agentes multiplicadores do projeto, realizaram-se treinamento para os agentes multiplicadores a fim de que todos usassem a mesma linguagem ao ministrar as palestras. Várias entidades envolveram-se, entre elas destacam-se: Rotaract, Câmara Jr., Lions, Rotary, Escoteiros, Arpa Fiúza, Secretaria Municipal de Educação e Cultura, Secretaria de Obras e Associação Comercial e Industrial de Panambi (ALMEIDA, 2003).

No início da implantação da coleta seletiva, essa passou a ser periódica, sendo que os resíduos orgânicos passaram a ser recolhidos nos bairros duas vezes por semana e no bairro Centro três vezes por semana. A divulgação do projeto de implantação da Coleta Seletiva foi através do Slogan "Lixo Separado - Meio Ambiente Preservado". Este slogan foi divulgado em parceria com as emissoras de rádio e jornais, utilizando também outros slogans, tais como: "Separe seu lixo, a natureza agradece", "Povo educado, lixo separado".

O Segundo Lugar de Depósito de Lixo / Usina de Reciclagem localizado na BR 158 deixou de receber lixo a partir da inauguração da Central de Triagem e Compostagem com Aterro Sanitário - CTCAS, em 06 de março de 2001.

A Figura 3 traz a delimitação do Segundo Lugar de Depósito de Resíduos Sólidos. A legenda apresenta a localização de pontos selecionados, os quais se referem à infraestrutura realizada com vistas à recuperação deste lugar e outros pontos apontam para problemas ambientais.

A delimitação na cor amarela na imagem aérea corresponde ao espaço que era depositado os resíduos, além do terreno que havia sido determinado para esta finalidade.. A Figura 2 mostra trecho do riacho (P.1 a P.4), onde foram realizadas três observações no período de janeiro de 2011 a dezembro de 2012 com intervalo de três meses. Nas observações notou-se a presença de resíduos diversos na água e preso as margens. Os resíduos sólidos estavam expostos e sem cobertura de terra.

No ponto (P.5) inicia o processo de canalização do riacho. Na margem esquerda do riacho observou-se grande quantidade de resíduos de jardinagem, que foram jogados pela população que reside nas proximidades. $\mathrm{Na}$ margem direita, há restos de madeira, plásticos, pneus, entre outros. Nas três observações em meses diferentes, durante o ano de 2012 percebia-se que a ação antrópica era recente. As construções de moradias existentes nas proximidades do riacho respeitam a legislação das APP's.

Nos pontos (P.6 e P.8) identificou-se uma enorme quantidade de resíduos descartados pela população apesar da Prefeitura Municipal disponibilizar serviços de coleta de porta em 
porta. No entorno do Primeiro Lugar de Depósito dos Resíduos Sólidos, na Rua da Palmeira tinha/ainda tem problemas ambientais, mas também se constata que foram realizados investimentos na Administração Municipal 2005 a 2008, isso é, foram construídos passeios pela Administração Pública Municipal ao longo da rua, parada de ônibus e as vias públicas foram asfaltadas. Esta parada de ônibus foi construída justamente em frente de parte do Primeiro Lugar que foi Depósito de Resíduos Sólidos até o ano de 1974.

No Primeiro Lugar de Depósito de Resíduos Sólidos o passivo ambiental é visível. Segundo a Associação Brasileira de Normas Técnicas (2007), os passivos ambientais são definidos como "danos infligidos ao meio natural por uma determinada atividade ou pelo conjunto de ações humanas, que podem ou não ser avaliados economicamente".

Em entrevista realizada com famílias que residem próximo ao Primeiro Lugar de Depósito de Resíduos Sólidos relatam que não foi realizado trabalho de recuperação, após a desativação do lixão e a paisagem que existe foi recompondo-se ao longo do tempo. Esse lugar não está cercado, existem vestígios de resíduos sólidos presentes no solo, após 37 anos de desativação.

Segundo os relatos dos descendentes de moradores que ainda residem neste local após a desativação do primeiro Lugar dos Resíduos Sólidos, foram construídos inúmeras residências e os terrenos, por estarem próximas do Centro da cidade, ou seja, da Praça Engenheiro Walter Faulhaber, voltaram à valorização e a especulação imobiliária.

O Segundo Lugar de Depósito de Resíduos Sólidos (1975 a 2001) no Município de Panambi foi adquirido de Nelita Weidle, conforme escritura pública lavrada em 06 de novembro de 1973, pelo tabelião Paulo Weber, a saber, uma fração de terras, com a área de oito (8) hectares e sete mil e quinhentos (7.500) metros quadrados, sem benfeitorias, situada na Linha Serrana, no município de Panambi, zona rural, confrontando ao norte, com terras da firma Kepler Weber S. A, ao sul e oeste, com terras de Aristeu Kersting, ao leste com terras da Prefeitura Municipal, cujo imóvel destina-se ao depósito e a conservação do lixo recolhi ło na cidade.

$\mathrm{Na}$ separação dos resíduos, entretanto, o plástico era um grande problema, pois era impossível a sua decomposição e este vinha geralmente mesclado junto com os materiais orgânicos, o que gerava odor e proporcionava um habitat perfeito para os insetos. Para dar fim ao grande volume de detritos que aumentava dia-a-dia, os plásticos eram queimados com o aval do Poder Executivo. Porém, reclamações começaram a ser feitas, pois a fumaça tóxica originada da queima dos plásticos era trazida pelo vento para a área urbana e algo deveria ser feito pelo Executivo para solucionar o problema.

Em 1984 o assunto da instalação de uma Usina de Reciclagem de Lixo Urbano surgiu por parte da Administração Pública Municipal de Panambi, porém, somente no segundo semestre de 1986 formou-se uma equipe para pensar na elaboração de um Projeto. Segundo relatos de gestores do município, o Projeto da Usina de Reciclagem de Lixo foi pensada e idealizada pela Administração Pública Municipal e começou a ser colocado em prática em julho de 1986. O modelo adotado na Usina de Reciclagem de Lixo passou a operar como um protótipo idealizado e constituído por indústrias, em conjunto com técnicos e engenheiros da Prefeitura e outros municípios passaram a adotar a sistemática.

Segundo registros nos jornais locais, nos primeiros quatro meses de experiência com a usina em operação, foram tratados 15 mil toneladas diárias e com a venda dos materiais recicláveis que eram separados e comercializados pela própria prefeitura, pagava $40 \%$ a $50 \%$ da folha de pagamento dos funcionários que trabalhavam na Usina de Reciclagem de Lixo (A NOTÍCIA ILUSTRADA, 1988).

Após a instalação da Usina de Reciclagem de Lixo na BR 158, o município recebeu visita de representantes de outros municípios do RS, SC, RJ além de representação da Argentina. Os 
visitantes tinham o objetivo de conhecer o protótipo da usina e saber mais detalhes sobre a eficiência da mesma.

O depósito de materiais recicláveis foi construído parte de alvenaria e parte em madeira. Este possuía vários boxes para colocar os materiais que eram separados pelos funcionários.

Em relação à retirada de entulhos provenientes da limpeza de quintais, a população precisava apenas solicitar a retirada ligando para o setor encarregado na Prefeitura. A Administração Pública Municipal (1989-1992) colocou em pontos estratégicos das vias públicas, nos diferentes bairros, recipientes coletivos próprios para o armazenamento dos resíduos domésticos, era para facilitar e agilizar o recolhimento dos resíduos urbano, tanto para os garis como para a população em geral, com a finalidade de deixar a cidade mais limpa. Também havia pessoal encarregado da limpeza pública e pintura dos cordões de meio fio em ruas principais, objetivando o embelezamento da cidade e a melhoria da área urbana (A NOTÍCIA ILUSTRADA, 1991).

Em 1992 a Administração Pública Municipal inscreveu vários projetos para concorrer a seleção de alguns que seriam apresentados na ECO 92. O município de Panambi foi selecionado entre os oitos semifinalistas de todo o Brasil, no Programa de Reconhecimento aos gestores locais, iniciativas das Nações Unidas que premiaram os municípios que estavam com projetos ou ações em andamento o qual tinha a finalidade de proteger o Meio Ambiente. Panambi destacouse no Projeto "Usina de Reciclagem e Compostagem do Lixo".

Em abril de 1997 houve um grande incêndio na usina de reciclagem de lixo (A NOTICIA ILUSTRADA, 1997), após este episódio, houve discussão nas emissoras de rádio e jornais locais sobre a possibilidade de implantação da coleta seletiva de resíduos sólidos. O gestor se pronunciou sobre o episódio, a Promotoria Pública enviou oficio solicitando medidas imediatas para solucionar o problema na Usina. Em fim foi dado ao gestor até o final da Administração Pública Municipal daquele período para relocar a Usina para outro espaço. Este novo espaço deveria ser longe do perímetro urbana.

A coleta seletiva de resíduos sólidos no município de Panambi (RS) teve início no mês de fevereiro de 2000, após estudos chegou-se a um cronograma que obteve êxito em diversas cidades, o qual baseava em escolher um bairro piloto, posterior implantação em toda a área urbana do município; foi elaborado e distribuído Calendário de Coleta Seletiva, o qual trazia/traz explicações e benefícios para a humanidade e meio ambiente e já com as datas de recolhimento do lixo orgânico e seco. Elaborou-se também um audiovisual, o qual-apresentava à cidade, o crescimento, as indústrias, a estrutura educacional, com texto elaborado a partir das imagens mostrando a usina e a unidade de Curitiba como exemplo. Realizaram-se palestras nas escolas contendo falas e o audiovisual sobre a educação ambiental, foram distribuídas cartilhas entre os alunos incentivando-os a serem agentes multiplicadores do projeto, realizaram-se treinamento para os agentes multiplicadores a fim de que todos usassem a mesma linguagem ao ministrar as palestras. Várias entidades envolveram-se, entre elas destacam-se: Rotaract, Câmara Jr., Lions, Rotary, Escoteiros, Arpa Fiúza, Secretaria Municipal de Educação e Cultura, Secretaria de Obras e Associação Comercial e Industrial de Panambi (ALMEIDA, 2003).

No início da implantação da coleta seletiva, essa passou a ser periódica, sendo que os resíduos orgânicos passaram a ser recolhidos nos bairros duas vezes por semana e no bairro Centro três vezes por semana. A divulgação do projeto de implantação da Coleta Seletiva foi através do Slogan "Lixo Separado - Meio Ambiente Preservado". Este slogan foi divulgado em parceria com as emissoras de rádio e jornais, utilizando também outros slogans, tais como: "Separe seu lixo, a natureza agradece", "Povo educado, lixo separado". 
O Segundo Lugar de Depósito de Lixo / Usina de Reciclagem localizado na BR 158 deixou de receber lixo a partir da inauguração da Central de Triagem e Compostagem com Aterro Sanitário - CTCAS, em 06 de março de 2001.

A Figura 3 traz a delimitação do Segundo Lugar de Depósito de Resíduos Sólidos. A legenda apresenta a localização de pontos selecionados, os quais se referem à infraestrutura realizada com vistas à recuperação deste lugar e outros pontos apontam para problemas ambientais.

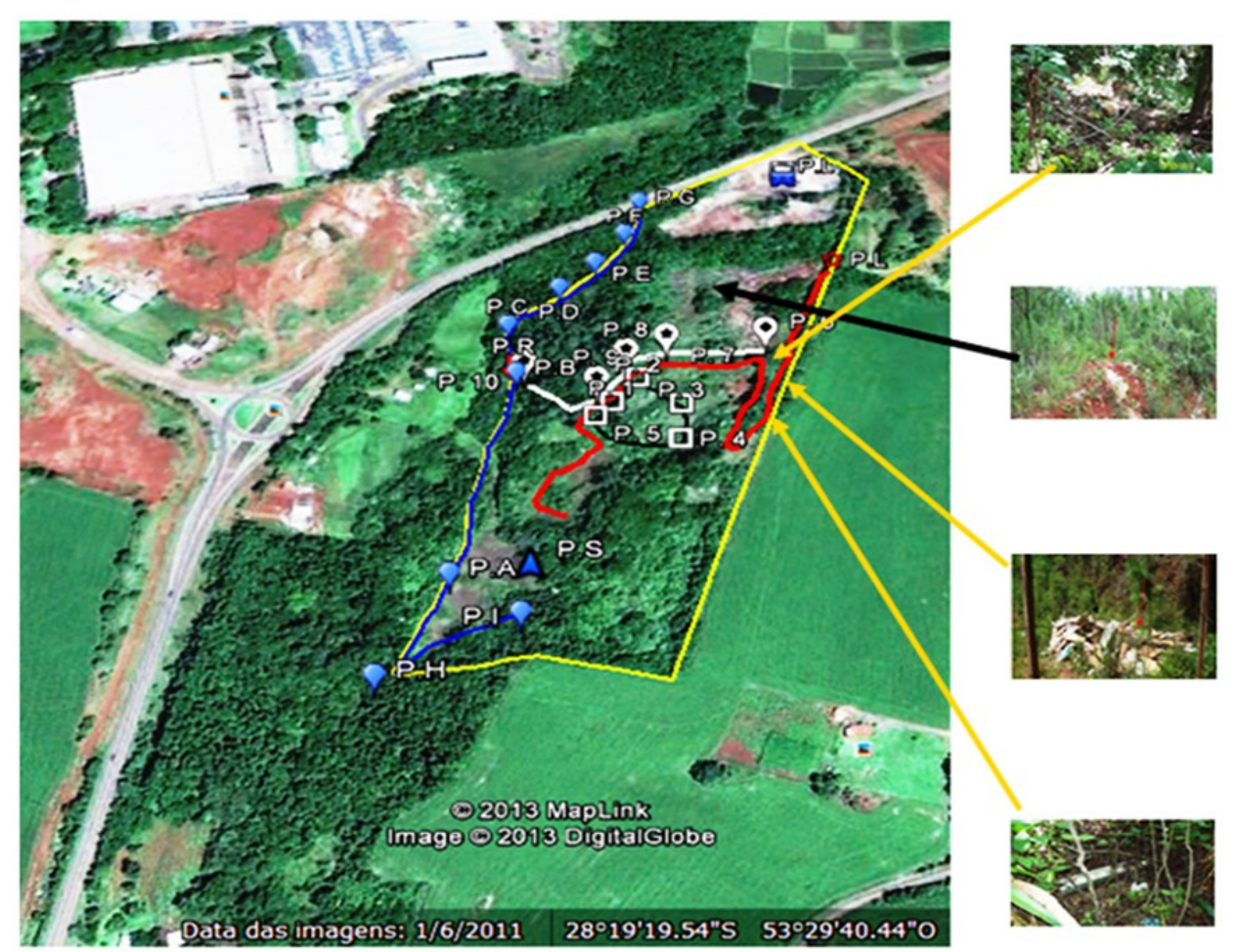

Figura 3- Imagem Área do Segundo Lugar de Depósito de Resíduos Sólidos /BR 158. Fonte: Google Earth e Trabalho de Campo, maio de 2012. Organizado pela Autora.

\section{Legenda}

\begin{tabular}{|l|}
\hline 回 P1 a P.5 \\
\hline P P.6 a P.10 \\
\hline P.A a P.I \\
\hline$\triangle$ P.S \\
\hline P.L \\
\hline P.R \\
\hline P.A \\
\hline
\end{tabular}

Cerca de Tela de Proteção da Lagoa

Demarcação da cerca onde foram plantadas espécies arbórec

Percurso do riacho que foram demarcados

Pedreira (a estrada para acesso necessita passar por dentro da área de preservação permanente).

Área cedida através de Contrato de Comodato - Reitex.

Passagem de gado para a área em recuperação.

Passagem de motos 
Os pontos (P.1 a P.5) constituem uma cerca de tela, a qual isola a lagoa que deveria receber o "chorume", construída por exigência das normas da FEPAM. Em observações realizadas em trabalho de campo não se percebe vestígios de entrada de chorume na lagoa, só contém água da chuva e alguns girinos. Na observação realizada em outubro de 2012 esta continua somente com água da chuva em torno de $30 \mathrm{~cm}$, de cor clara.

Os pontos (P.6 a P.10) traz a demarcação de uma cerca com arame construída pela Prefeitura Municipal, por solicitação do Conselho Municipal do Meio Ambiente de Panambi, após o plantio de espécies arbóreas. Esta ação teve por finalidade auxiliar na recuperação da área uma vez que tinha sido depósito de resíduos sólidos.

Percebe-se que apesar do depósito de resíduos ter sido desativado em março de 2001 e ter colocado em prática o projeto de recuperação de área degradada na administração 2005 a 2008, ainda é visível os problemas ambientais e as ações antrópicas.

O plantio de espécimes pela Arpa Fiúza em anos anteriores estão se recuperaram nas partes onde não há acesso dos animais e nem ação antrópica. Em visita ao local em outubro de 2012 notou-se que a cerca de proteção às espécies arbóreas está arrebentada e grande parte dos arames está danificado (TRABALHO DE CAMPO, 2012).

As imagens dos problemas ambientais apresentados na Figura 3 (restos de materiais de construções, vidros quebrados em grande quantidade, lâmpadas fluorescentes, restos de fiação elétrica, entre outros materiais), estão expostos no solo, onde a vegetação está aos poucos crescendo e se recompondo.

O ponto (PS) localiza a área que pertence à pedreira, esta área foi desmembrada da área que pertencia ao Segundo Depósito de Resíduos Sólidos no segundo semestre de 2012, a fim de dar entrada num Projeto para exploração da pedreira, com o objetivo de utilizar o material extraído na mesma no calçamento das ruas da cidade. O projeto para exploração da pedreira foi terceirizada pela Administração Pública Municipal de Panambi/RS, para, a Empresa GEOMAC Mineração e Meio Ambiente Ltda, que elaborou o Relatório Geológico do Meio Físico da Pedreira Saibreira, localizada na Linha Serrana. De posse do Relatório a Prefeitura encaminhou o Processo de Registro ao Departamento Nacional de Produção Mineral. O referido registro de extração é o $\mathrm{n}^{\mathrm{o}} 17$, de 3 de março de 2012. A área desmembrada corresponde a dois hectares de terras dos 8.750 metros que pertencia ao Segundo Lugar de Depósito de Resíduos Sólidos. A pedreira foi Licenciada pela FEPAM, a partir de outubro de 2012.

Em trabalho de campo realizado anterior a contratação da Empresa GEOMAC Mineração, em fevereiro de 2012, notou-se que as máquinas (retroescavadeira e caminhões) percorriam a estrada dentro da área de preservação permanente para retirar as pedras. $\mathrm{O}$ solo na estrada onde é realizado o trajeto para retirar o material extraído da pedreira está ficando desprotegido e compactado, ou seja, são visíveis as camadas de resíduos no lugar, que em 2001, foi desativada a usina de resíduos e foi considerada área de preservação permanente. A pedreira situa-se na localidade de Linha Serrana, próximo a BR 158, a leste da cidade de Panambi, no Noroeste do RS. As coordenadas UTM (Fuso 22 J) Datum SAD69 para localização da área. UTM X - 255322.009 e Y - 6864623.909. Para explorar a pedreira, há necessidade de passar dentro da área de preservação ambiental.

Em visita ao Segundo Lugar de Depósito de Resíduos Sólidos utilizado pela Administração Pública Municipal, em outubro de 2012 constatou-se que motoqueiros possuem uma trilha costeando a pedreira e passam por dentro do riacho (P.A) mencionada na legenda da Figura 3, ocasionando erosão e destruição de ambas as margens.

Em 24 de fevereiro de 2012 através das observações na área de preservação do Segundo Lugar de Depósito de Resíduos Sólidos/ Antiga Usina - BR 158 constatou-se que foi inserida na 
paisagem grande quantidade de galhos caixas de abelhas, as mesmas estavam espalhadas logo na entrada de acesso ao portão. Em outubro de 2012 novamente o local foi observado e constatou-se foi inserida uma quantidade maior de caixas de abelhas. Segundo depoimento de representante do Conselho do Meio Ambiente (2012), as caixas de abelhas foram inseridas na paisagem por um apicultor de abelha, com autorização do Conselho Municipal do Meio Ambiente e do Gestor Público Municipal. Para ^stes: quanto mais abelhas tiver neste local, menos invasões ocorrerão na área de preservação e as abelhas, também contribuem para a polinização.

O terceiro Lugar de Depósito de Resíduos Sólidos (2001 a 2012) utilizado atualmente pela Administração Pública Municipal, localiza-se na Linha Rincão Frente, distante $4 \mathrm{~km}$ da área urbana de Panambi/RS. Neste lugar há o aterro sanitário e a usina de triagem.

A aquisição de um novo lugar para relocalização do aterro e instalação da usina de triagem e compostagem com aterro sanitário teve a participação de opiniões diversas dos Poderes Executivo e Legislativo, do Ministério Público, das Secretarias Municipais, dos Órgãos da Segurança Pública, da Associação Comercial e Industrial de Panambi - ACI, da ONG Arpa Fiúza, entre outras entidades.

A Administração Pública Municipal apresentou em reunião a opção de duas áreas que havia para a relocalização da Usina de Reciclagem. A escolha se deu com auxílio da Comissão de Saúde e Meio Ambiente da Associação dos Munícipios do RS-FAMURS.

A área possui cento e setenta e nove mil, quarenta e sete metros e trinta e três decímetros quadrados (179.047,33 $\left.\mathrm{m}^{2}\right)$. Foi desapropriada de forma amigável, sendo a mesma declarada de utilidade pública, para fins de implantação de "Usina de Reciclagem de Lixo". O valor pago foi de oitenta e cinco mil reais (R\$ 85.000,00). O município de Panambi - Administração Pública Municipal, doou o imóvel com as descrições acima descritas para o Consórcio Intermunicipal de Tratamento de Resíduos Sólidos Urbanos -"Centro de Tratamento".

No período de 1997 a 2000 foram dados os primeiros passos para a relocalização da Usina de Triagem e Compostagem de Lixo que estava localizada na BR 158. A partir da inauguração da nova Central Triagem e Compostagem com Aterro Sanitário em Rincão Frente, os resíduos passaram a ser recolhidos também da cidade de Condor (ALMEIDA, 2003) devido ao Consórcio firmado entre os municípios de Condor e Panambi.

A lei $\mathrm{n}^{\circ} 1.758$ de 09 de setembro 1999 autorizou a Administração Pública Municipal, a formar Consórcio com outros municípios. Trata da elaboração em conjunto com os municípios consorciados de um regulamento do serviço e utilização da CTCAS, bem como os critérios sobre a disposição do lixo processado. A usina de reciclagem de lixo teve suas atividades iniciais com a Licença de Operação n ${ }^{\circ}$ 2401/2001.

Em 2001 quando foi inaugurada a Usina de Triagem, localizada em Rincão Frente, está dispunha dos seguintes equipamentos: uma esteira de taliscas, uma esteira de captação, três prensas enfardadeiras, uma moega, um caminhão basculante, uma retro escavadeira ou carregadeira, carrinhos ou vagonetes de rodas para transporte de material (resíduos), uma oficina e almoxarifado, um Box para beneficiamento e estocagem de composto orgânico coberto e com uma peneira e um Box para depósito de recicláveis (PRAD, 2005).

Os resíduos orgânicos que chegavam a Usina de Triagem (2001 a 2004), após a pesagem eram diretamente levados às pilhas de lixo, em vazadouros situados em diversos pontos da área, margeando o caminho de serviço que cortava a área de oeste para leste, entre a mata nativa e estrada na direção norte, entre as lagoas e o limite da mata, na direção noroeste. Já os resíduos de podas realizadas nas árvores dos municípios de Panambi e Condor eram depositados, bem como os depósitos de construção civil na região nordeste da Central, contornando o capão nativo, próximo a uma drenagem intermitente. A Licença de Operação da Usina de Triagem inspirou em 23 de junho de 2003. Para que esta fosse renovada havia necessidade de fazer uma série de 
ajustes no lugar onde estava localizada a Usina. Foram realizadas as seguintes solicitações por parte da FEPAM. Apresentação de um projeto de recuperação para os dois últimos lugares que haviam sido depositados resíduos; Notificações de todas as empresas do Município que enviam resíduos caracterizados como industriais ao local da sua interdição de fazê-lo; Isolamento, da mata em preservação, da massa de resíduos; Fechamento das laterais do galpão de reciclagem; Cronograma de peneiramento da totalidade dos resíduos enviados para compostagem, entre outros. No final do período de 2001-2004 a situação na Usina pode ser visualizada na Figura 4.

No período compreendido entre 2001 a 2004 foram realizados serviços de compostagem, porém não foi levado em consideração normas da FEPAM. Em 2002, a coleta de tratamento de resíduos da saúde foi terceirizada. Porém o antigo depósito de serviços de saúde permaneceu até 2005, até que providências foram tomadas, a fim de desativar o mesmo. Em relação à cobertura vegetal percebeu-se que houve avanço no crescimento, apresenta espécies nativas e exóticas em diferentes pontos. A Figura 4 mostra e ilustra os principais problemas que existiam na Usina de Triagem, em Rincão Frente, no início de 2005.

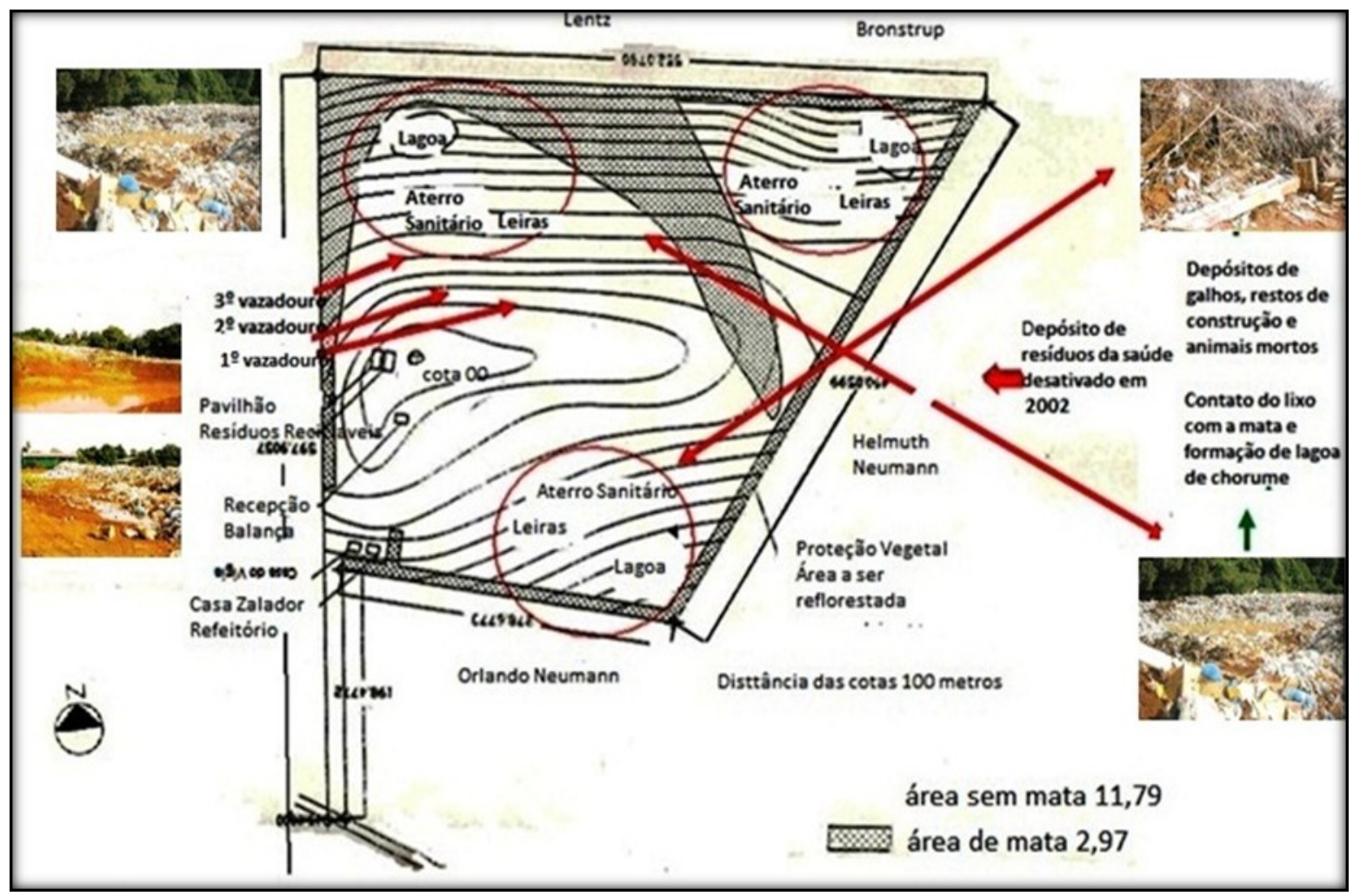

Figura 4 - Planta da Usina de Reciclagem / CTCAS da Prefeitura Municipal (1999), Interpretada e Adaptada pela Autora (jan. 2012) Utilizando-se das Informações do Projeto Recuperação de Área Degradada - PRAD (2005)

No período (2005 a 2008) foram realizadas licitações para elaboração de um Projeto com vistas a recuperar o Terceiro Lugar de Depósito de Resíduos Sólidos, onde se encontrava localizada a Usina de Triagem, na Linha Rincão Frente e para recuperar o Segundo Lugar que havia sido Depósito de Resíduos Sólidos.

Os Projetos de Recuperação de Áreas Degradadas (2005), após rigoroso levantamento in loco da situação da área da Usina de Triagem com vistas à solicitação da renovação do Alvará para Licença de Operação foi norteada pela adequação à legislação ambiental vigente, instruções 
técnicas da FEPAM/DISA, para projetos de central de triagem e compostagem com aterro sanitário de rejeitos, roteiros da FEPAM, entre outros.

O Plano de Recuperação de Área Degradada foi elaborado pela Empresa STC Tratamento de Resíduos Ltda em 2005 e foi executado pela Empresa Transportes J. C. Lopes Ltda, vencedora da licitação. Essa empresa conforme previa a licitação, realizou os serviços de engenharia e saneamento na Usina de Reciclagem - Rincão Frente e BR 158-Usina de Reciclagem desativada em 2001, também realizaram-se serviços de terraplanagem, escavação, drenagem e demais obras para a execução do projeto que previa a destinação final dos resíduos sólidos encontrados em ambos os locais (PREFEITURA MUNICIPAL DE PANAMBI, 2005).

$\mathrm{O}$ aterro sanitário, em Rincão Frente foi dimensionado para operar com segurança e eficácia até o ano de 2025, levando em consideração a recepção e tratamento de todos os resíduos em vazadouro, desde a inauguração que aconteceu em 6 de março de 2001.

No dia 02 de abril de 2007, após adequações dos dois lugares conforme orientação do PRAD (2005), a Administração Pública Municipal assinou o contrato de terceirização da coleta, triagem e destinação final do lixo doméstico produzido em Panambi. Segundo informações da Administração Pública Municipal (2007), a assinatura do contrato foi realizada na Usina de Reciclagem de Resíduos Sólidos Urbanos, na mesma ocasião em que a Prefeitura recebeu oficialmente a obra de recuperação da área a qual exigiu investimentos em torno de $\mathrm{R} \$ 450$ mil dos cofres públicos municipais.

Segundo a Administração Pública Municipal o recebimento da obra assim como a terceirização do serviço representou um importante salto de qualidade no atendimento às necessidades da comunidade panambiense. A recuperação do lugar, ou seja, da área onde estava localizada a Usina de Reciclagem de Lixo, agora com a denominação de CTCAS, era uma exigência legal e foi necessário cumprir evitando problemas ambientais ainda mais sérios para a população panambiense.

Apesar dos serviços terem sidos terceirizados, o calendário de coleta seletiva nos bairros e no centro da cidade mantiveram-se, apenas o horário de recolhimento do lixo no bairro Centro que passou a ser realizado a partir das $18 \mathrm{~h}$. Os servidores públicos municipais que atuavam na usina de lixo foram remanejados para outras secretarias (ENTREVISTA, PREFEITURA MUNICIPAL DE PANAMBI, 2007).

A expectativa da terceirização foi à melhoria nos serviços de coleta, triagem e também destinação final dos resíduos. Nos anos de 2007 e 2008 os serviços na CTCAS ficaram por conta de uma empresa terceirizada. Os serviços de varrição e limpeza dos meios fios permaneceram com a Administração Pública Municipal. Os serviços na Central de Triagem e Compostagem com Aterro Sanitário deixaram de ser terceirizados a partir do mês de janeiro de 2009.

A CTCAS está ligada à Secretaria Fazenda e Desenvolvimento que engloba Agricultura, Indústria, Comércio, Turismo, Meio Ambiente e Serviços. A usina está licenciada pela FEPAM com prazo de validade até 2012 (ENTREVISTAS, INFORMAÇÕES VERBAIS, 2011).

Para a atividade da coleta dos resíduos são utilizados quatro caminhões truck. A coleta é realizada todos os dias conforme o cronograma que foi implantado já algum tempo.

$\mathrm{Na}$ Administração Pública Municipal que iniciou em 2009 houve pequenas alterações, isto é, os resíduos sólidos (lixos) no Bairro Centro passou a ser recolhido todos os dias e nos bairros Erica e São Jorge que era recolhido na sábado passou para a sexta feira no mesmo horário. Segundo informações verbais do gestor público atual, no ano de 2011 foram adquiridos dois caminhões baús para a Coleta do Lixo. Esta terceirizou os resíduos provenientes da saúde. Este tipo de terceirização está previsto conforme Monteiro (2001, p.12).

Os serviços de coleta são realizados por vinte e quatro operários, sendo que doze operários (garis) trabalham na coleta diária nos caminhões e doze na CTCAS na varrição das 
ruas. Durante o ano de 2009, houve problemas com o recolhimento de lixo, mas aos poucos foram sendo equilibrados e a situação praticamente normalizada. Um dos problemas foi e continua sendo a dificuldade na separação dos resíduos orgânicos e reciclável no bairro Centro, que não chega a atingir $50 \%$ do lixo recolhido diariamente. Nos demais bairros, existe a preocupação maior em separar o lixo seco do orgânico, o que facilita o trabalho de recolhimento e também de separação na Usina. Também é realizada a coleta de lixo especial, como móveis velhos entre outros (FETTER, 2009).

A Administração Pública Municipal está apertando o cerco contra o depósito clandestino de lixo em locais de preservação, principalmente nas proximidades do leito ou na margem dos rios. Em março de 2010, o departamento de coleta de lixo da Prefeitura instalou quatro novas lixeiras na Travessa Carlos Hisserich, que segundo o Coordenador do departamento de recolhimento de lixo, a medida tem como objetivo disciplinar o acondicionamento do lixo no local. Isso significa que, duas das lixeiras instaladas serão destinadas ao lixo orgânico e as outras duas, ao lixo reciclável (ENTREVISTAS, INFORMAÇÕES VERBAIS, 2010).

No segundo semestre de 2012 deu-se início a construção de uma nova célula para o aterro sanitário. No final do primeiro semestre de 2012 foi nomeada Comissão Técnica através da Portaria 526/2012 de 11 de julho de 2012 para elaboração do Plano Municipal de Gestão Integrada de Resíduos Sólidos. Integra a Comissão seis funcionários públicos municipais, estes trabalharam na elaboração do Plano. No dia 26 de setembro de 2012 em evento organizado pelo Conselho Municipal do Meio Ambiente de Panambi, foi apresentado por um funcionário público integrante da Comissão. Segundo este funcionário o plano está em fase de elaboração.

A Figura 5 traz a delimitação do Terceiro Lugar de Depósito de Resíduos Sólidos, atual CTCAS - Central Triagem e Compostagem com Aterro Sanitário - Rincão Frente e a infraestrutura existente desde o início do primeiro ano de funcionamento em março de 2001.

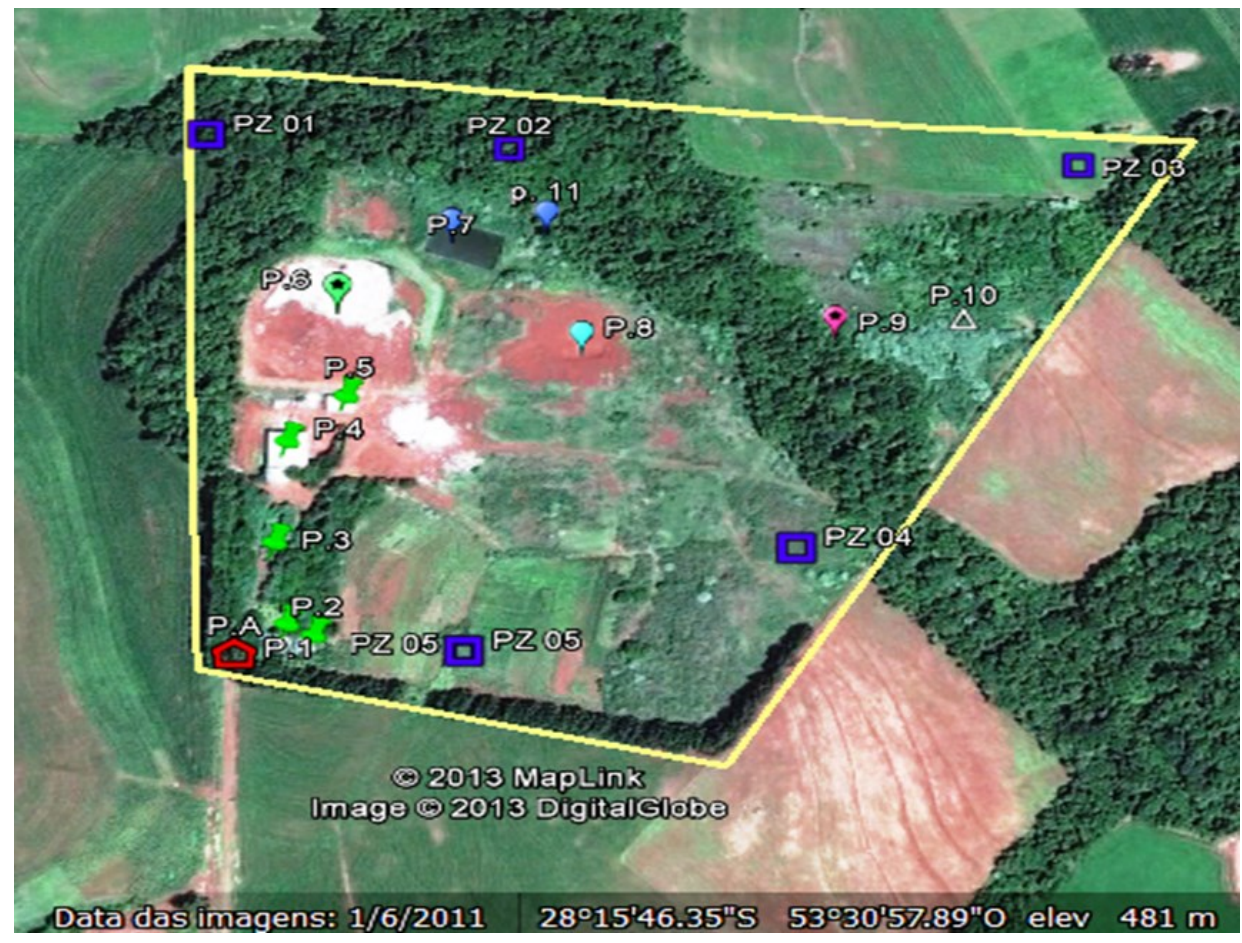

Figura 5 - Terceiro Lugar de Depósito de Resíduos Sólidos - atual CTCAS - Rincão Frente e Infraestrutura Existente Desde o Primeiro Ano de Funcionamento (2001), 2013. Fonte: Google Earth. Elaborado pela Autora. 
Legenda

\begin{tabular}{|c|c|}
\hline$\Delta_{\text {P.A }}$ & Portão de Acesso a CTCAS - Rincão Frente \\
\hline$\beta_{P .1}$ & Casa do Zelador \\
\hline$\beta_{\text {P.2 }}$ & Banheiros e Refeitórios \\
\hline$\beta_{P .3}$ & Balança e Guarita \\
\hline$\beta_{\text {P.4 }}$ & Pavilhão de recebimento de resíduos recicláveis \\
\hline$\beta_{\text {P.5 }}$ & Aterro Sanitário \\
\hline$\beta_{\text {P.6 }}$ & Box - Depósito de Materiais Recicláveis \\
\hline$P_{\text {P.7 }}$ & Lagoa Anaeróbica \\
\hline Р P.8 & Terra utilizada no Aterro Sanitário \\
\hline$\sqrt{\text { P.9 }}$ & Depósito de Restos de Galhos \\
\hline$\Delta \mathrm{P} .10$ & Cemitério de Animais \\
\hline P P.11 & Água/ Lagoa Anaeróbica \\
\hline \begin{tabular}{|l|l}
$\square$ & \\
\end{tabular} & Piezômetros \\
\hline
\end{tabular}

A legenda apresenta a localização da infraestrutura existente na atual Central de Triagem e Compostagem com Aterro Sanitário.Em trabalho de campo realizado percebe-se as mudanças relacionadas a paisagem no decorrer dos anos de 2001 data da instalação aos dias atuais. Também ocorrerram alterações nas construções, isto é, foi ampliado o galpão onde são depositados os resíduos recicláveis.

Foram entrevistados os funcionários que trabalhavam diretamente na CTCAS, os quais puderam expor as suas opiniões positivas e negativas em relação aos serviços que são realizados na CTCAS. Também foi elaborada uma cronologia com ações dos Administradores Públicos Municipais com relação aos resíduos sólidos, desde a emancipação a dezembro de 2012.

\section{Conclusão e Recomendações Finais}

O foco principal desta pesquisa foram os três lugares de depósitos de resíduos sólidos, utilizados pelas Administrações Públicas municipais desde a emancipação (1955) aos dias atuais (2012) no município de Panambi-RS.

Foi de extrema importância conhecer, pesquisar e analisar os três lugares onde foram depósitos de resíduos, pois cada um destes lugares possuem marcas deixadas pelas diferentes Administrações Públicas. Também foi importante conhecer o perfil dos trabalhadores que desempenham suas funções na atual usina de triagem com aterro sanitário, bem como conhecer a função que cada um desempenha no dia-a-dia.

No município de Panambi, desde a emancipação até o ano de 2012, quatro dos gestores foram eleitos mais de uma vez. O que se percebeu que os gestores que assumiram mais de uma gestão, possuem opiniões diferentes em suas administrações com relação aos lugares de ocupação e utilização onde foram os depósitos de resíduos sólidos no município. Embora tenha havido avanços na gestão dos resíduos no município de Panambi, RS, alguns problemas básicos ainda permanecem sem solução entre os quais podem-se destacar: 
- A FEPAM passou aos municípios a responsabilidade de emitirem licenças ambientais para empreendimentos de baixo potencial poluidor existente no município. Este deve monitorar estas atividades e verificar se estão de acordo com a legislação. Nos três lugares de pesquisa há indícios de agressões ao meio ambiente. Isto é, a FEPAM passou aos municípios a responsabilidade de emitir licenças ambientais, quando o próprio município não dá bons exemplos;

- O município explora uma pedreira quando esta se localiza a menos de 50 metros de um afluente do rio principal que abastece a cidade. A FEPAM emitiu licença para a prefeitura municipal explorar a pedreira, porém fere a legislação, pois os funcionários da prefeitura para explorar a pedreira, necessitam passar por dentro da área de preservação ambiental;

- No início da Administração Municipal 2009 - 2012 foi autorizado e depositado grande quantidade de galhos na área de preservação ambiental (segundo lugar de depósitos de resíduos sólidos, desativado em 2001);

- O Termo de Aditivo de Conduta assinado com o Ministério Público na Administração Pública anterior não foi cumprido pela municipalidade dentro da data prevista;

- A Administração Pública Municipal autoriza o depósito de resíduos de construções na área de preservação ambiental, quando deveria proibir esta ação e dar exemplo;

- Na área de preservação ambiental há grande quantidade de caixas de abelhas;

- Próximo ao aterro sanitário em Rincão Frente, existe uma horta onde são cultivadas diversas hortaliças, entre outros;

- Muitas indústrias depositam os seus resíduos na usina de triagem, quando deveria dar fim aos seus próprios resíduos conforme diz a legislação;

- Os resíduos das indústrias locais depositados na usina, não são identificados quando chegam à recepção pela pessoa responsável;

Após pesquisa nos três lugares que foram depósitos de resíduos sólidos, incluindo entrevistas com Administradores Públicos Municipais, Secretários Municipais, Funcionários da Administração Pública, entre outros recomenda-se ao A Administração Pública Municipal:

- Criação com urgência de um Departamento de Limpeza Pública, com responsável que tenha formação na área;

- Oportunize aos funcionários que trabalham na Central de Triagem com Aterro Sanitário sugerirem os melhoramentos com vistas a obter melhores resultados, com os diversos serviços que realizam com relação aos resíduos;

- Melhore as condições de infraestrutura no refeitório, pois nem todos os funcionários conseguem espaço para fazer as refeições;

- Ofereça a primeira refeição aos funcionários logo ao chegarem à usina e merenda em intervalos da manhã e tarde, pois pesquisas comprovam que se o funcionário estiver bem alimentado com certeza terá mais disposição para realizar o trabalho;

- Seja construído maior número de banheiros masculinos e femininos, próximo ao prédio onde são realizadas as diferentes frentes de trabalho;

- Realize reunião mensal com todos os funcionários que trabalhavam na Central de Triagem com Aterro Sanitário e mostre os resultados obtidos com o trabalho de cada um, pois com certeza se sentirão mais valorizados;

- Construa metas com os funcionários com relação aos serviços de separação, triagem e comercialização dos resíduos sólidos;

- Oportunize momentos de formação em serviço a todos os funcionários da usina;

- Iniciem novamente aos serviços de compostagem na usina, realizando a capacitação dos funcionários para realizarem os trabalhos;

- Forneça uniformes ( mascaras e luvas ), para realizar os serviços na usina; 
- Exija o uso de uniforme para realização dos serviços de recolhimento dos resíduos;

- Realize campanhas sobre a separação dos resíduos sólidos nas escolas, nos bairros, nas emissoras de rádio e nos jornais locais.

- Reorganize o calendário de recolhimento de resíduo em relação aos tipos. Exemplo. Os papeis e vidros não há necessidade de recolher toda a semana, ter um dia especial. Adotando um dia especial no mês para recolhimento dos vidros e outro para os diferentes tipos de papéis;

- Seja realizada o controle dos veículos de terceiros que circulam e levam resíduos para a usina de triagem;

- Crie uma cooperativas de catadores de resíduos sólidos (garrafas pet, latinhas, vidros);

- Elabore e coloque em prática um Plano de Carreira, "premiando os funcionários" que são assíduos ao serviço;

- Crie parcerias com o Conselho Municipal do Meio Ambiente e Secretaria Municipal de Educação e Cultura e juntos programarem visitação a usina de resíduos sólidos e palestras nas Escolas, entre outras atividades relacionadas aos resíduos sólidos;

- Realize palestras por funcionários da Secretaria do Meio Ambiente e do Departamento de Limpeza Pública Municipal nos centros comunitários dos bairros, etc;

- Divulgue o valor da arrecadação anual proveniente dos serviços da usina e aonde foi aplicado.

A realização dessa pesquisa comprova que existe uma evolução no gerenciamento dos serviços de recolhimento e tratamento dos resíduos sólidos desde a época da emancipação aos dias atuais no município de Panambi/RS. É possível perceber as diferentes formas de administração dos vários gestores e sabe-se que tem muito que fazer ainda em relação aos serviços na atual usina de triagem.

Esta pesquisa é apenas um subsídio para novos trabalhos. Questões levantadas na realização do presente estudo espera-se, que possam ser aprofundadas em futuras pesquisas.

\section{Referências}

ABRELPE-Associação Brasileira de Empresas de Limpeza Pública e Resíduos Especiais, Situação dos Municípios em Relação ao Recolhimento do Lixo de 2009 a 2011 . Disponível em:< http://www.abrelpe.org.br/>. Acesso em: 05 mar. 2012.

ALMEIDA, R. E. Saneamento Básico: Abastecimento e Qualidade da Água em Panambi. Monografia do Curso de Geografia, UNIJUI, 2003.

A NOTICIA ILUSTRADA. Retirada de entulhos, limpeza em quintais deve ser comunicado ao setor de obras. 06 de nov. 1991. MAHP. 1988, p.8.

Usina de Lixo. Eficiência e simplicidade de operação,

A Notícia Ilustrada, Jornais consultados no Museu e Arquivo Histórico Professor Hermann Wegermann (1968 a 1980).

CALLAI, H. C. Estudar o lugar para entender o mundo. In: Ensino de Geografia Práticas e Contextualizações no Cotidiano, São Paulo: Ed. Mediação, 2000.

Ensino de Geografia: contextualizações no cotidiano. Porto Alegre: Mediação, 2000.p. 83-131. Cap. 2. 
CASTRO, J. M. A. Resíduos perigosos no direito ambiental internacional - sua internalização nos países do MERCOSUL. $1^{\mathrm{a}}$ ed. Porto Alegre: Sérgio Antônio Fabris, 2003.

CUSTÓDIO, H. B. Legislação ambiental e proteção da paisagem. OLAM- Ciências \& Tecnologias. Rio Claro. Vol. 2 n 1, p.58-94, abr/2002.

CLAVAL, P. A Geografia cultural: Florianópolis: ed. da UFSC, 1999.

ENTREVISTAS, INFORMAÇÕES VERBAIS concedidas a Cléa Hempe. TRENTINI, Ovídio, WENGRAT, P. ARPA FIÚZA. Visitas aos Lugares de Depósitos de Resíduos Sólidos, 2008, 2009, 2010 e 2011.

ENTREVISTAS COM GESTORES, EX-GESTORES, INFORMAÇÕES VERBAIS concedidas a Cléa Hempe. Lugares de Depósitos de Resíduos Sólidos utilizadas pelas Administrações Públicas 1955-2012. nov. 2009.

FETTER, V.. Limpeza urbana apresenta relatório. Jornal Folha das Máquinas de 06 de

LIBÓRIO M. G. C. A paisagem e sua proteção através de mecanismos legais. Disponívelem:<http://observatoriogeograficoamericalatina.org.mx/egal3/Procesosambient ales/Geomorfologia/04.pdf>. Acesso: 26 dez. 2011.

MONTEIRO, J. H. P. Manual de Gerenciamento Integrado de Resíduos Sólidos. Instituto de Administração Municipal - IBAM, 2001.

O PANAMBIENSE. Jornais. Disponíveis no Museu Arquivo Históricos Professor Hermann Wegermann. Consultados em 2011.

PANAMBI. PLANOS DIRETORES. Disponíveis no Museu Arquivo Históricos Professor Hermann Wegermann.

PANAMBI (RS) PREFEITURA MUNICIPAL. Licitação para recuperação de área degradada do lixão em Rincão Frente, 2005, Prefeitura Municipal de Panambi. Disponível em: $<\underline{\text { http://www.guiadigital.info/index.php?not }=1 \& \text { pesq_not }=1 \& \operatorname{mostra}=2695}>$. Acesso em: 20 jan. 2012.

PRAD - Projeto de Recuperação e Área Degradada. Central de Triagem e Compostagem com Aterro Sanitário de Resíduos Sólidos Urbanos. Processo 005385-05.67/042. Elaborado por STC Tratamento de Resíduos Ltda, jun. 2005. 